\title{
BACTERIAL SYMBIONTS OF SOFT CORAL LOBOPHYTUM SP. FROM PANJANG ISLAND, JEPARA, INDONESIA WITH ANTIMICROBIAL MDR TB POTENCY
}

\author{
Yuvianti Dwi Franyoto ${ }^{1}$, Ahmad Fuad Masduqi ${ }^{1}$, Sakti Muchlisin ${ }^{2}$, Prasetyo Abi \\ Widyananto $^{2}$, Sulistiyani ${ }^{3}$, Diah Permata Wijayanti ${ }^{4}$, Lia Kusmita ${ }^{1, *}$ \\ ${ }^{1}$ STIFAR "Yayasan Pharmasi Semarang" Semarang, Indonesia \\ ${ }^{2}$ Tropical Marine Biotechnology Laboratory, Diponegoro University, \\ Semarang 50275, Indonesia \\ ${ }^{3}$ Faculty of Public Health, Diponegoro University, Semarang 50275, Indonesia \\ ${ }^{4}$ Faculty of Fisheries and Marine Science, Diponegoro University, \\ Semarang 50275, Indonesia \\ *Corresponding Author: lia_kusmita@yahoo.com
}

\begin{abstract}
Tuberculosis is a disease that attacks the lungs. The disease is caused by the bacterium Mycobacterium tuberculosis. The bacteria M. tuberculosis can be killed by antibiotics. However, continuous use of antibiotics can cause bacterial resistance. This study aims to determine the antibacterial activity of MDR TB from soft coral symbiont bacteria Lobophytum sp. The sample was collected and identification for colony morphology. An antibacterial preliminary test is conducting using the overlay method. Secondary metabolites extraction from bacterial was assayed for antibacterial activity. Bacterial symbiont was conducted for genomic DNA for molecular identification. There were six bacterial isolates obtained from soft coral Lobophytum sp. One isolate from Lobophytum-associated bacteria was successfully screened for antimycobacterial against MDR TB bacteria. PLO2 was found to inhibit the growth of MDR TB (MDR TB strain SIRE and R). Based on the results of identification with PCR, soft coral symbionts of PLO2 was closely related to Virgibacillus marismortui with homology of $99 \%$.
\end{abstract}

Keywords: $\quad$ bacterial symbiont, Lobophytum sp., MDR TB, Virgibacillus marismortui

Submitted on: 18 October 2018

Accepted on: 14 January 2019

DOI: https://doi.org/10.25026/jtpc.v4i5.200

\section{INTRODUCTION}

Several years ago, there was high confidence about the decline in defense of infectious diseases because of advances in technology and science. However, due to an increase in the transitional nature of infectious diseases, such beliefs have not been met. Worldwide infectious diseases information is still the leading cause of death, especially in developing countries, 
claiming millions of lives yearly despite the enormous improvements made in human healthcare [1]. Treatment of infectious diseases has faced a major problem with a growing number of microbes developing mechanisms for antibiotic resistance and widely used antiviral therapy [2]. A few examples are the pathogens associated with and multidrug-resistant tuberculosis (MDR TB).

Tuberculosis is a highly contagious disease with about one-third of the world's sufferers. However, this problem is serious because Mycobacterium tuberculosis has developed a resistance mechanism for firstline treatment as well as second-line drugs. This has led to the emergence of $M$. tuberculosis (MDR), which is resistant to multiple drugs (MDR) and extensive drug resistance (XDR) throughout the world. Thus, overcoming the problem of infectious diseases is now an essential and urgent requirement.

Organisms in the sea including coral reef ecosystems have become a source of natural chemical products that are very interesting because they provide most of the sources of bioactive metabolite compounds with various biological activities [3]. The development of marine organisms derived compounds into drugs has been hampered by supply limitations [4].Symbiosis between microorganisms and marine organisms is abundant and widespread in the oceans [5] There is evidence that many of the previously identified marine soft coral secondary metabolites are of microbial origin [6]. Their ability to survive in this competitive environment could be due to their own adaptation, in addition to or perhaps because of the microbial communities be due to their adaptation, in addition to or perhaps because of the microbial communities, they harbor [7].
The ability of the soft coral in the bioactive compound due to the symbiotic relationship with microorganisms in this bacteria. This relationship includes the provision of nutrition by helping translocations metabolism including nitrification, nitrogen fixation, photosynthesis and helps chemical defenses as well as play a role in biofouling. Because of this the role of bacterial symbiotes then soft coral to have a high potential in generating bioactive compounds that had been isolated from the soft coral [8]. This potential allows symbiotic bacteria in the soft coral to produce bioactive compounds and replace soft coral that has produced bioactive compounds. Bacteria are capable of producing rapidly bimossa content so that bioactive lives can be produced more easily, quickly and more in the scale of biotechnology than in soft coral culture itself [9].

\section{MATERIALS AND METHOD}

\section{Sample Preparation}

Sampling and isolation bacterial symbionts Colonies of soft coral Lobophytum sp. were collected by scuba diving from Panjang islands, Jepara, North Java Sea, Indonesia (Figure 1).

Upon collection, soft corals were put into sterile plastic bags (Whirl-Pak, Nasco USA). The tissue was then rinsed with sterile seawater and homogenized with a blender. The homogenized tissues were serially diluted, spread on half strength ZoBell 2216E marine agar medium and incubated at room temperature for $2 \times 24$ hours. By morphological features, colonies were randomly picked and purified by making streak plates [10]. Purification was conducted by separation of colony morphology (color, shapes, margin, and texture). 


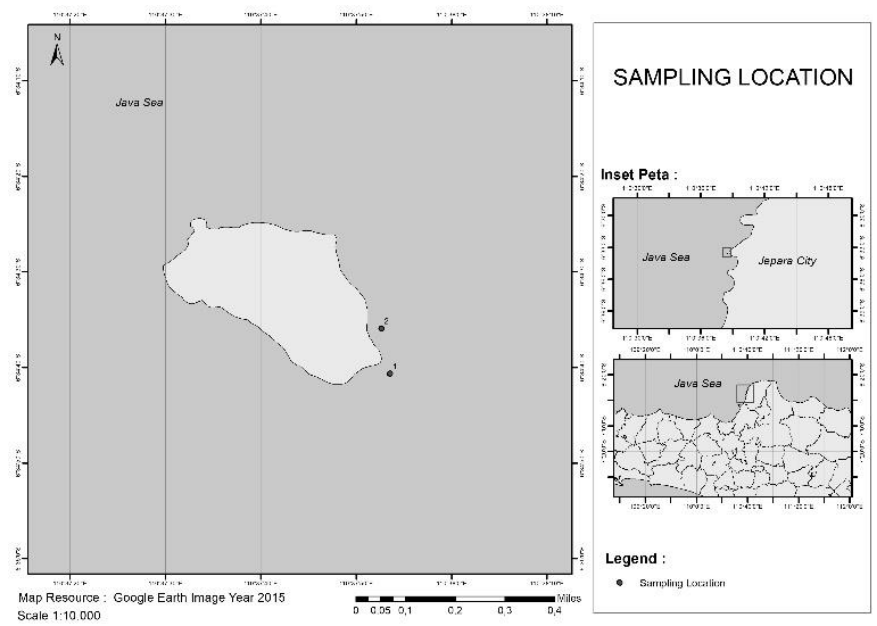

Figure 1. Sampling location of Lobophytum sp.

\section{Antibacterial preliminary test}

MDR TB strain SIRE (Mycobacterium tuberculosis) resistant Streptomycin, Isoniazid, Rifampicin and Ethambutol) and strain R (Mycobacterium tuberculosis resistant Rifampicin) was obtained from the Health Laboratory of Central Java Province-Semarang. This test was conducted using the overlay method [11]. The culture of each bacterium in the logarithmic phase was mixed with Middle brook 7H9+OADC soft agar medium (1\% $\mathrm{v} / \mathrm{v})$, which were poured on to the respective agar surface previously inoculated with Lobophytum sp. associated bacteria that incubated for four days at room temperature. Then the plates were incubated at room temperature $2 \times 24$ hours. Inhibition zone showed that bacterium produced potential bioactive compound against MDR-TB. Furthermore only the most potential isolate was extracted of its secondary metabolites

\section{Secondary Metabolites Extraction of Potential Isolate}

Extraction was initially started with growing the associated bacterium into Zobell agar medium. Collected pellets, and the pellet was extraction using methanol with the aid of a sonicator. The crude extract was filtered using filter paper Whatman no. 1. Afterward, extract was then dried by the use of rotary evaporator and nitrogen $\left(\mathrm{N}_{2}\right)$ gas flow [12].

\section{Antibacterial Test}

This test was performed using the disk diffusion method. The crude extract from potential isolate was tested in various concentration. The concentration started from 10, 20, 30, 40, and $50 \%$. An inoculum of MDR TB strain SIRE and strain $\mathrm{R}$ with density of $0.5 \mathrm{McF}$ arland in blended with Middle brook 7H9+OADC soft agar medium $(1 \% \mathrm{v} / \mathrm{v})$. Crude extracts were on the blank paper disc, then incubated for $2 \times 24$ hours at room temperature. Antibacterial activity was the formation of clear zones around the MDR TB bacterial colonies [11].

\section{Phytochemical Screening}

Crude extract was evaluated by phytochemical qualitative reactions for secondary metabolites. The screening was performed for phenol, terpenoid, alkaloids, steroids, flavonoids, saponins, tannins, and triterpenoid. The color intensity or the 
precipitate formation was used as analytical responses to these tests [13-15].

\section{Molecular Identification}

The genomic DNA of bacterial symbiont was conducted using chelex [16]. Amplification was done using PCR with Eubacteria universal primers $27 \mathrm{~F}$ (5'AGAGTTTGATCMTGGCTCAG-3'), and primer 1492 TACGGYTACCTTGTTACGACTT-3') [17]. The proses of denaturation were initially at $94^{\circ} \mathrm{C}$ for 2 minutes and then successive denaturation $\left(94^{\circ} \mathrm{C}\right.$ for $\left.1 \mathrm{~min}\right)$, annealing $\left(55^{\circ} \mathrm{C}\right.$ for $\left.1 \mathrm{~min}\right)$, and extension $\left(72{ }^{\circ} \mathrm{C}\right.$ for $\left.2 \mathrm{~min}\right)$. A series of denaturation, annealing, and extension were repeated 45 times. Furthermore, the gel electrophoresis was conducted to see the DNA bands formed. PCR amplification or partialm16S rRNA gene of Lobophytum sp. associated bacteria and subsequent sequencing analysis were performed according to a method of Altschul [18] and Radjasa [19].

\section{RESULT AND DISCUSSION}

\section{Identification of Lobophytum sp.}

Lobophytum sp. sample used in this research ware take from Panjang Island, Jepara (Figure 2). The morphology identification is shown in table 1. Softcoral genus Lobophytum sp. have several secondary metabolites, such as alkaloids, steroids, triterpenoids, flavonoids, saponins, phenols and terpenoids [20]. Terpenoids from Lobophytum sp. have a potential antibacterial activity[20, 21].

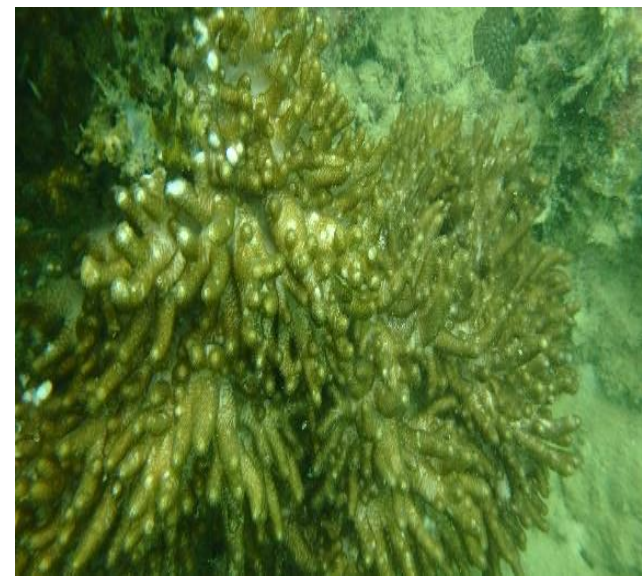

(a)

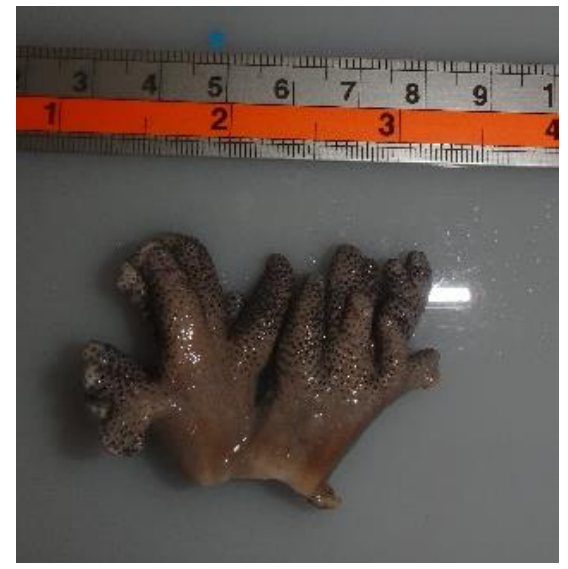

(b)

Figure 2. Lobophytum sp. (a) in the sea and (b) on land

Table 1. The morphology identification bacteria symbiont from soft coral Lobophytum sp.

\begin{tabular}{llllll}
\hline No & Bacterial Code & Coulour & Shape & Margin & Elevation \\
\hline 1. & PLO1 & White & Irregular & Undulated & Curved \\
2. & PLO2 & Milk White & Irregular & Undulated & Flat \\
3. & PLO3 & Yellow & Circular & Intact & Flat \\
4. & PLO4 & Yelow & Irregular & Undulated & Flat \\
5. & PLO5 & White & Dots & Intact & Flat \\
6 & PLO6 & White & Circular & Intact & Curved \\
\hline
\end{tabular}


Inhibition Zone on MDR TB

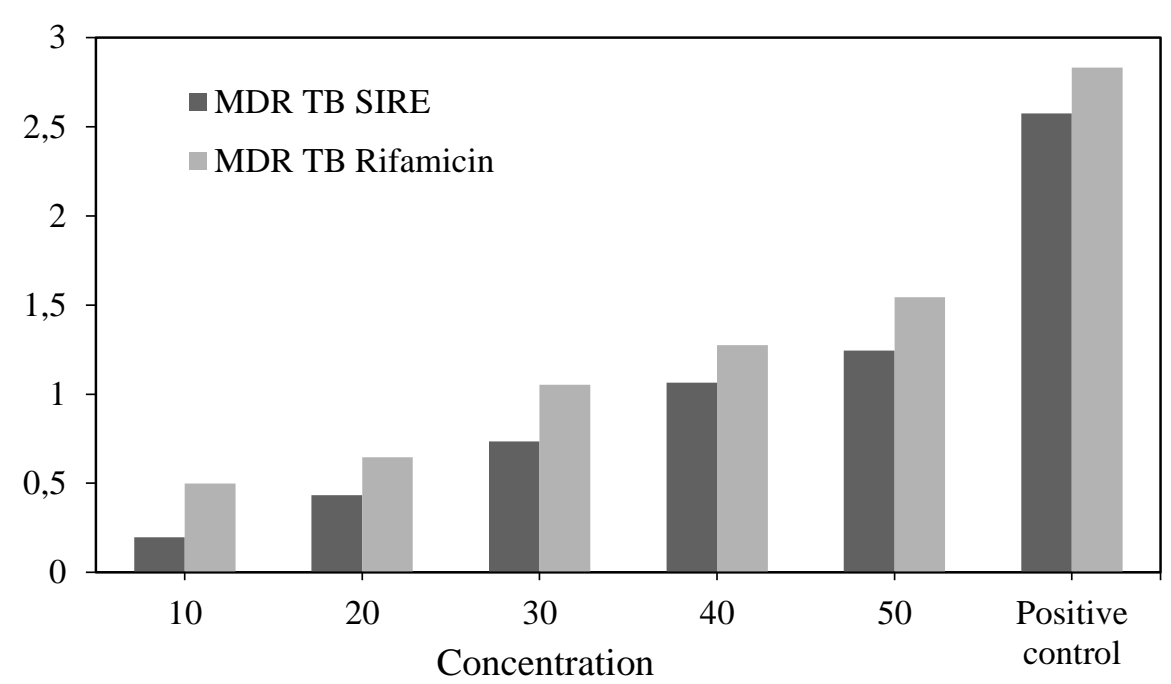

Figure 3. Bacteria activity test

Table 3. Phytochemical screening secondary metabolite from bacterial symbiont PLO2

\begin{tabular}{ccc}
\hline No & Secondary metabolite & Explanation \\
\hline 1. & Phenol & - \\
2. & Tannins & - \\
3. & Alkaloids & + \\
4. & Steroids & - \\
5. & Flavonoids & - \\
6. & Saponins & - \\
7. & Terpenoid & + \\
8. & Triterpenoid & + \\
\hline
\end{tabular}

There was six isolates from symbiont bacteria soft coral Lobophytum sp. The result confirmed that marine organism such as Lobophytum sp. thrive in symbiosis with other microorganisms (bacteria) [22]. Bacterial will be symbiotic with their host. There are several factors that influences the quality and quantity of bacterial symbionts in the host that changes temperature, climate, and intensity to sun exposure [23].

\section{Antibacterial preliminary test}

The overlay test MDR TB from bacteria symbiont Lobophytum sp. shown in table 2. Overlay rest result shows that of the six bacterial isolates there was one isolate showing activity against bacteria MDR TB. Multidrug-resistant tuberculosis (MDR TB) that used for this research were MDR TB strain SIRE, and MDR TB strain R. SIRE is the first line drugs to patient tuberculosis. Microorganisms associated with marine invertebrates producing secondary metabolites are bioactive compounds that have the potential as a drug and Pharmaceutical dosage [22, 23]. According to to [24] that bacterial symbionts of Lobophytum sp. have activity against MDR bacteria. 


\section{Antibacterial Test}

The results of antibacterial activity test on symbiont bacteria extract against MDR bacteria are presented in Figure. 3. One isolate was chose because they have activity against bacteria MDR TB. Isolates $\mathrm{PLO} 2$ were tested in MDR TB with five different concentrations. Their potential antibacterial was from secondary metabolites microorganism that produced when bacteria cell finished the logarithmic phase and going into stationer phase. Secondary metabolites of microorganism can be derived from the conversion primary metabolite; this phase is called idiophase [25].

\section{Phytochemical Screening}

Phytochemical screening secondary metabolite from bacterial symbiont PLO2 shown in table 3. In the present study, crude extract from bacterial symbiont PLO2 showed positive results for alkaloids, terpenoid, and triterpenoid. Bacteria symbiotically associated with soft corals can synthesize secondary metabolites similar to host [26]. The antibacterial mechanism of alkaloids is attributed to their ability to intercalate with DNA. Moreover, the mechanism of terpenoid is not fully understood but is speculated to involve membrane disruption by the lipophilic compounds [27].

\section{Molecular Identification}

PCR method used to dertemine to molecular identification bacteria symbiont with Lobophytum sp. [24]. DNA sequencing of $16 \mathrm{~S}$ rDNA from PLO2 isolate:

GCGGCTGGCTCCAAAAGGTTACCTC ACCGACTTCGGGTGTTACCAACTCT CGTGGTGTGACGGGCGGTGTGTAC AAGGCCCGGGAACGTATTCACCGC GGCATGCTGATCCGCGATTACTAGC GATTCCGGCTTCATGCAGGCGAGTT GCAGCCTGCAATCCGAACTGAGAA TGGTTTTATGGGATTTGCTTGACCT CGCGGCTTCGCTGCCCTTTGTTCCA TCCATTGTAGCACGTGTGTAGCCCA GGTCATAAGGGGCATGATGATTTG ACGTCATCCCCACCTTCCTCCGGTT TGTCACCGGCAGTCACCTTAGAGTG CCCAACTAAATGCNGGCAACTAAG ATCAAGGGTTGCGCTCGTTGCGGGA CTTAACCCAACATCTCACGACACGA GCTGACNACAACCATGCACCACCT GTCACTCTGTCCCCCAAGGGAACAT CCTATCTCTAGGATTGGCAGAGGAT GTCAAGACCTGGTAAGGTTCTTCGC GTTGCTTCG

Below is a bacterial symbiont homology search using the BLAST system, presented in table 4. And phylogenic tree shown in Figure 4. Phylogenic tree shown the phylogenetic affiliation of bacterial isolate with othe microorganism.

Table 4. Symbionts Bacteria Homology Search Results Using BLAST

\begin{tabular}{lccccc}
\hline No & $\begin{array}{c}\text { Isolate } \\
\text { Code }\end{array}$ & $\begin{array}{c}\text { Nukleotide } \\
\text { Length (bp) }\end{array}$ & Closest relative & $\begin{array}{c}\text { Accession } \\
\text { Number }\end{array}$ & $\begin{array}{c}\text { Homology } \\
(\%)\end{array}$ \\
\hline 1. & P.Lo 2 & 502 & Virgibacillus marismortui & NR_028873 & 99 \\
\hline
\end{tabular}




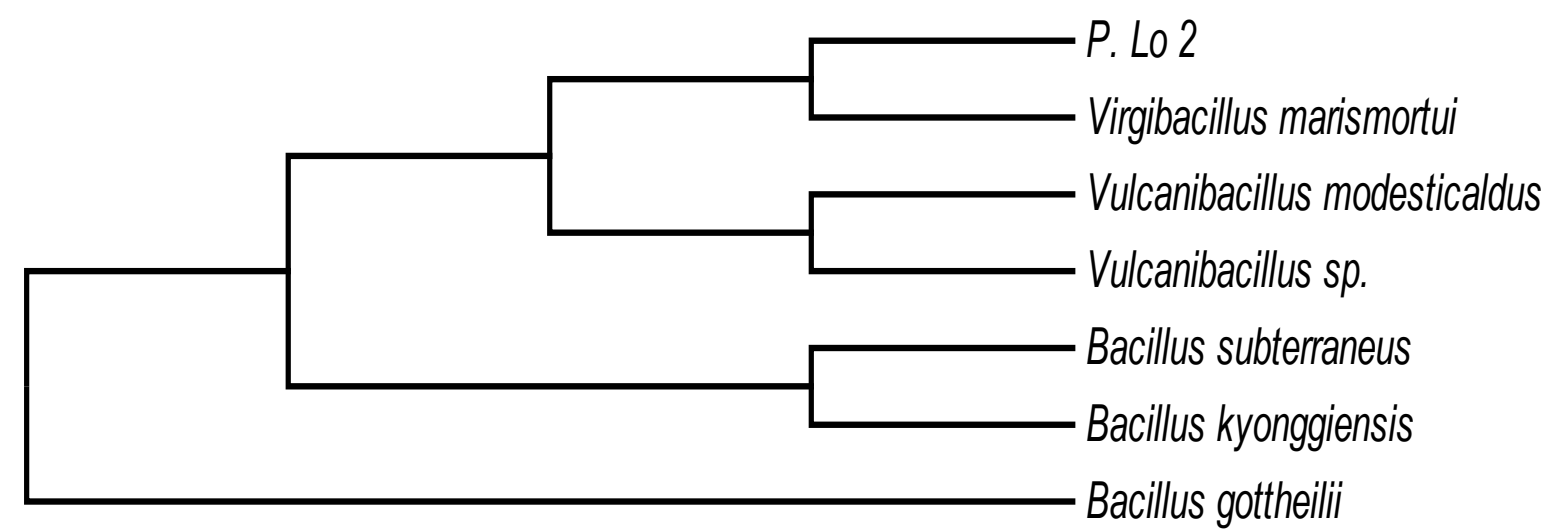

Figure 4. Phylogenic tree from bacterial simbionts PLO2 from Lobophytum sp.

Molecular identification using the BLAST system, by search for the bacterial homology. Isolate PLO2 was strictly related to Virgibacillus marismortui with 99\% homology value. [28, 29] state that isolates which has $16 \mathrm{~S}$ rDNA sequence similarity more than $97 \%$ can be represented at the species level. While the sequence similarities between $93-97 \%$ can represent identity at the genus level. It can be concluded that PLO2 have a level similarity in species. Virgibacillus marismortui is a species of Gram-positive, it can be obligate aerobs. [30, 31] found that bacterial Virgibacillus marismortui from Dead Sea water and deteriorated mural paintings.

\section{CONCLUSION}

PLO2 symbiotic bacteria from Lobophytum sp have antibacterial activity against MDR TB strain SIRE and strain R. Isolate PLO2 identified as Virgibacillus marismortui based on accesion NR_028873

\section{ACKNOWLEDGMENT}

The authors thank the Directorate of Research and Community Services, Ministry of Research, Technology and Higher Education, and the Republic of Indonesia for financial support to this research through "PEKERTI" research grant scheme.

\section{REFERENCES}

[1] York, T., De Wet, H., Van Vuuren, S., 2011. Plants used for treating respiratory infections in rural Maputaland, KwaZulu-Natal, South Africa. Journal of ethnopharmacology. 135. 696-710.

[2] Chen, Y.-L., Huang, S.-T., Sun, F.M., Chiang, Y.-L., Chiang, C.-J., Tsai, C.-M., Weng, C.-J., 2011. Transformation of cinnamic acid from trans-to cis-form raises a notable bactericidal and synergistic activity against multiple-drug resistant Mycobacterium tuberculosis. European Journal of Pharmaceutical Sciences. 43. 188194.

[3] Faulkner, D. J., 2000. Marine pharmacology. Antonie van leeuwenhoek. 77. 135-145.

[4] Piel, J., 2006. Bacterial symbionts: prospects for the sustainable production of invertebrate-derived pharmaceuticals.

Current medicinal chemistry. 13. 39-50.

[5] Muscholl-Silberhorn, A., Thiel, V., Imhoff, J. F., 2008. Abundance and bioactivity of cultured spongeassociated bacteria from the Mediterranean Sea. Microbial Ecology. 55. 94-106.

[6] Xi, L., Ruan, J., Huang, Y., 2012. Diversity and biosynthetic potential 
of culturable actinomycetes associated with marine sponges in the China seas. International journal of molecular sciences. 13. 5917-5932.

[7] Zeng, Z., Zhao, J., Ke, C., Wang, D., 2013. Antimicrobial activities of novel cultivable bacteria isolated from marine sponge Tedania anhelans. Chinese journal of oceanology and limnology. $\mathbf{3 1}$. 581-590.

[8] Lee, Y. K., Lee, J.-H., Lee, H. K., 2001. Microbial symbiosis in marine sponges. JOURNAL OF MICROBIOLOGY-SEOUL-. 39. 254-264.

[9] Thiel, V., 2006. Sponge-associated bacteria: specificity, diversity and antimicrobial potential. ChristianAlbrechts-Universität.

[10] Madigan, M. T., Martinko, J. M., Parker, J., 1997. Brock biology of microorganisms. Prentice hall Upper Saddle River, NJ.

[11] Sulistiyani, S., Nugraheni, S. A., Radjasa, O. K., Sabdono, A., Khoeri, M. M., 2010. Antibacterial activities of bacterial symbionts of soft coral Sinularia sp. against tuberculosis bacteria. Journal of Coastal Development. 14. 45-50.

[12] Kusmita, L., Mutiara, E. V., Nuryadi, H., Pratama, P. A., Wiguna, A. S., Radjasa, O. K., 2017. Characterization of carotenoid pigments from bacterial symbionts of soft-coral Sarcophyton sp. from North Java Sea. International Aquatic Research. 9. 61-69.

[13] Khan, F. A., Hussain, I., Farooq, S., Ahmad, M., Arif, M., Rehman, I. U., 2011. Phytochemical screening of some Pakistanian medicinal plants. Middle-East J Sci Res. 8. 575-578.
[14] Yadav, R., Agarwala, M., 2011. Phytochemical analysis of some medicinal plants. Journal of phytology.

[15] Khayyat, S., Al-Kattan, M. O., 2017. Phytochemical screening and antimicrobial activities of Costus speciosus and Sea Qust. Biomedical Research. 28.

[16] Walsh, P. S., Metzger, D. A., Higuchi, R., 1991. Chelex 100 as a medium for simple extraction of DNA for PCR-based typing from forensic material. Biotechniques. 10. 506-513.

[17] Long, R. A., Azam, F., 2001. Antagonistic interactions among marine pelagic bacteria. Applied and environmental microbiology. 67. 4975-4983.

[18] Altschul, S. F., Madden, T. L., Schäffer, A. A., Zhang, J., Zhang, Z., Miller, W., Lipman, D. J., 1997. Gapped BLAST and PSI-BLAST: a new generation of protein database search programs. Nucleic acids research. 25. 3389-3402.

[19] Radjasa, O. K., Khoeri, M. M., Darusallam, C. C., Trimasanto, H., Sudoyo, H., 2013. Bacterial symbionts of reef invertebrates: screening for anti-pathogenic bacteria activity. Biodiversity. 14. 80-86.

[20] Putra, M. Y., Murniasih, T., Swasono, R. T., Wibowo, J. T., Saputri, A. N. C., Widhiana, M. R., Arlyza, I. S., 2016. Secondary metabolites and their biological activities in Indonesian soft coral of the genus Lobophytum. Asian Pacific Journal of Tropical Biomedicine. 6. 909-913.

[21] Effendi, H., Soedharma, D., Kawaroe, M., Subhan, B., Arafat, D., Trisyulianti I. 2016. Potential bioactivity of artificially fragmented soft coral Sinularia sp. 
and Lobophytum sp. transplantation. International Journal of Pharmaceutical and Clinical Research. 8(5): 481-484.

[22] Bahry, M. S., Pringgenies, D. and Trianto, A. 2016. Molecular Identification of Marine Symbiont Bacteria of Gastropods from the Waters of the Krakal Coast Yogyakarta and Its Potential as a Multi-drug Resistant (MDR) Antibacterial Agent. International Symposium on Applied Chemistry (ISAC).

[23] Romanenko, L. A. Uchino, M., Kalinovskaya, N. I., Mikhailova, V. V. 2008. Isolation, phylogenetic analysis and screening of marine mollusc-associated bacteria for antimicrobial, hemolytic and surface activities. Microbiological Research. 163(6): 633-644.

[24] Murti, P. D. B. and Radjasa, O. K. 2012. Antibacterial Activity Of Bacterial Symbionts Of Soft Coral Lobophytum sp. Against MDR Bacteria Escherichia coli and Staphyllococcus aureus. Journal of Coastal Development. 15(3): 297302.

[25] Sulistiyani, Wahjono, H., Radjasa, O. K., Sabdono, A., Khoeri, M. M., Karyana, 2015. Antimycobacterial Activities from Seagrass Enhalus sp. Associated Bacteria Against Multi Drug Resistance Tuberculosis (MDR TB) Bacteria. Procedia Environmental Sciences. 23: 253259.

[26] Burgess, J. G., Boyd, K., Armstrong, E., Jiang, Z., Yan, L., Berggren, M., May, U., Pisacane, T., Granmo, A., Adams, D. R. 2003. The Development of a Marine Natural Product-based Antifouling Paint The
Development of a Marine Natural Product-based Antifouling Paint. Biofouling. 19: $197-205$.

[27] Cowan, M. 1999. Plant Product as Antimicrobial Agent. Clinical Microbiology Review. 12 (4): 564582.

[28] Hagström, A., J.U.L. 2000. Pinhassi and Zweifel. Biogeographical Diversity Among Marine Bacterioplankton. Aquat. Microb. Ecol. 21 : 231-244.

[29] da Silva M. A. C., Cavalett, A., Spinner, A., Rosa, D. C., Jasper, R. B., Quecine, M. C., Bonatelli, M. L., Pizzirani-Kleiner, A., Corção, G., Lima, A. O. S. 2013. Phylogenetic identification of marine bacteria isolated from deepsea sediments of the eastern South Atlantic Ocean. SpringerPlus. 2: 110. doi: 10.1186/2193-1801-2-127.

[30] Arahal, D. R., Márquez, M. C., Volcani, B. E., Schleifer, K. H. \& Ventosa, A. 1999. Bacillus marismortui sp. nov., a new moderately halophilic species from the Dead Sea. Int J Syst Bacteriol. 49: 521-530.

[31] Heyrman, L., Logan, N. A., Busse, H., Balcaen, A., Lebbe, L., Rodriguez-Diaz, M., Swings, J., Vos P. D. 2003. Virgibacillus carmonensis sp. nov., Virgibacillus necropolis sp. nov. and Virgibacillus picturae sp. nov., three novel species isolated from deteriorated mural paintings, transfer of the species of the genus salibacillus to Virgibacillus, as Virgibacillus marismortui comb. nov. and Virgibacillus salexigens comb. nov., and emended description of the genus Virgibacillus. Int. J. Syst. Evol. Microbiol. 53:501-511. 